\title{
THE EFFECT OF SUPPLY CHAIN LINKAGE ON MICRO AND SMALL ENTERPRISES' PERFORMANCE
}

\author{
Siti Aisyah Ya'kob \\ Universiti Malaysia Sarawak \\ Wan Jamaliah Wan Jusoh \\ International Islamic University Malaysia
}

\begin{abstract}
The practice of linking the enterprises with their channel members through supply chain activities is meant to achieve better performance and to create a win-win situation for both sides. A study on supply chain linkages is necessary in order to observe the effect of the linkages on firms' performance. Therefore, this study is conducted to examine the factors of supply chain linkages that affect the business performance among micro and small enterprises. Three factors were proposed, which are information sharing, development programme and outsourcing. A total of 214 sets of questionnaires was completed by owners and firm's personnel from 13 industrial sectors. The findings from this study revealed that information sharing and development programme have a significant and positive relationship with firms' performance. Even though outsourcing shows a positive relationship with firms' performance, but the relationship was not statistically significant. The results provide a better understanding of information sharing, development programme and outsourcing from micro and small enterprise perspective in Sarawak.
\end{abstract}

Keywords: Supply Chain; Information Sharing; Development Programme; Outsourcing; Performance; Micro and Small Enterprise.

\section{INTRODUCTION}

Small and medium industry represents $97 \%$ of the total businesses in Malaysia (The Borneo Post, 2012). In the Malaysian situation, small and medium enterprises can be considered as an important sector as this sector has contributed 32.5\% of the Gross Domestic Products (GDP) in 2011 (Mahalingam, 2012). A strong small and medium sector is important as it is the key driver for nation development (The Borneo Post, 2012).

Thus, this study intends to examine the factors of supply chain linkages that affect the business performance among micro and small enterprises in Kuching, Sarawak. In Malaysia, most of the owners of small and medium enterprises do not generally utilize information technology (Hashim, 2007), which is a tool for information sharing. Enterprises in Malaysia also lack

- Corresponding author: Siti Aisyah Ya'kob, Faculty of Economics and Business, Universiti Malaysia Sarawak, 94300 Kota Samarahan, Sarawak, Malaysia. Tel: +6082-581000 ext.4383. Email: ysaisyah@unimas.my 
skilled employees. This reduces the quality, efficiency, productivity and the ability to utilize the technical assistance and advisory services (Saleh \& Ndubisi, 2006). This is probably the reason for participation in development programmes organized by channel members (Kaliappan, Alavi, Abdullah \& Zakaullah, 2009). However, findings from another study revealed that the development programmes failed to improve business performances (Abdul-Aziz and Ali, 2004). Furthermore, small and medium enterprises have insufficient capacity to provide for the entire business functions. They also have limited resources, hence, outsourcing some of the activities is probably more efficient rather than implementing them internally (AbdulHalim, Ahmad and Ramayah, 2012). Therefore, a study on information sharing, development programmes and outsourcing is crucial in order to observe the impacts of those linkages on enterprise performance.

The rapid development in Sarawak has attracted micro and small enterprises to flourish. Kuching was selected as the research area and the survey will be conducted by approaching the micro and small enterprises' owner and employees. The participation will be restricted to the micro and small enterprises that operate in Kuching.

Consequently, the objectives of this study are:

i. To examine the relationship between information sharing, development programme, outsourcing and business performance within micro and small enterprises in Kuching, Sarawak and,

ii. To identify the most influential factor that affects the business performance within micro and small enterprises in Kuching, Sarawak.

\section{LITERATURE REVIEWS}

\subsection{Small and Medium Enterprises}

According to Hashim and Abdullah (2000), there are two perspectives relating to small and medium enterprises. To the government, the perspective is to provide assistance programmes and to financial institutions. However, the private perspective is for loan offerings. The two perspectives are to provide for controlling programmes, improving the policies as well as facilitating financial assistance (Ong, Hishamuddin and Yeap; 2010). The size of the enterprises is usually determined by quantitative attributes. The term "small and medium enterprises" is based on an SME Corp definition that is officially used to measure enterprise size in the local Malaysian context. The criteria used are the number of employees and cycle of sales (Kementerian Kewangan Malaysia ${ }^{1}$, 2003). In general, enterprises are divided into three categories, namely, micro enterprise, small enterprise and medium enterprise. Table 1 illustrates the interpretation of enterprises from SME Corp point of view.

In Malaysia, small and medium industry is dominated by micro enterprise (Ong et al., 2010) and only a small percentage of micro enterprises are able to achieve a superior performance while a huge portion of enterprises fails to perform (Kee, Effendi, Abdul Talib and Abdul 
Table 1: The Definitions of Small and Medium Enterprises by Size

\begin{tabular}{|c|c|c|c|}
\hline SME Category & Micro Enterprise & Small Enterprise & Medium Enterprise \\
\hline $\begin{array}{l}\text { Manufacturing, } \\
\text { Manufacturing- } \\
\text { Related } \\
\text { Services and Agro- } \\
\text { based industries. }\end{array}$ & $\begin{array}{l}\text { Sales turnover of less } \\
\text { than RM250,000 OR } \\
\text { full time employees } \\
\text { less than } 5 \text {. }\end{array}$ & $\begin{array}{l}\text { Sales turnover } \\
\text { between } \\
\text { RM250,000 and less } \\
\text { than RM10 million } \\
\text { OR full time } \\
\text { employees between } \\
5 \text { and } 50 .\end{array}$ & $\begin{array}{l}\text { Sales turnover } \\
\text { between RM10 } \\
\text { million and RM25 } \\
\text { million OR full time } \\
\text { employees between } \\
51 \text { and } 150 .\end{array}$ \\
\hline $\begin{array}{l}\text { Services, Primary } \\
\text { Agriculture and } \\
\text { Information \& } \\
\text { Communication } \\
\text { Technology (ICT). }\end{array}$ & $\begin{array}{l}\text { Sales turnover of less } \\
\text { than RM200,000 OR } \\
\text { full time employees } \\
\text { less than } 5 .\end{array}$ & $\begin{array}{l}\text { Sales turnover } \\
\text { between } \\
\text { RM200,000 and less } \\
\text { than RM1 million } \\
\text { OR full time } \\
\text { employees between } \\
5 \text { and } 19 .\end{array}$ & $\begin{array}{l}\text { Sales turnover } \\
\text { between RM1 } \\
\text { million and RM5 } \\
\text { million OR full time } \\
\text { employees between } \\
20 \text { and } 50 .\end{array}$ \\
\hline
\end{tabular}

Source: Adopted from SME Corp Malaysia website, retrieved June 6, 2013.

Rani, 2010). Enterprises fall under small and medium industry has low performance and this is related to a weak capability of institutions and agencies in facilitating the effective assistance programmes (Kee, et al., 2010).

\subsection{Business Performance}

Schmitz and Platts (2003) described firm performance as a "measurement of input, processes and outcome within one organization". Firm performance can be assessed based on financial and non-financial criteria (Gunasekaran, Patel, \& McGaughey, 2004). On one hand, financial performance refers to the inbound and outbound activities that involve transactions of costs such as warehousing, stocking inventory, and asset turnover. On the other hand, non-financial performance may include aspects such as order fulfillment rate, inventory turns, safety stocks, obsolete products as well as numbers of product warranty claims. However, there is no conclusive agreement on the methods of measuring firms' performance (Fabbe-costes \& Jahre, 2007). Shepherd and Gunter (2006) indicated that firms prefer financial performance (42\%) over non-financial performance which includes quality $(28 \%)$, time (19\%), flexibility (10\%), and innovativeness (1\%). Gunasekaran et al. (2004) also supported the idea that management is concerned with the financial achievements of the firm. Based on the literatures, both financial and non-financial performance measures have their advantages and disadvantages.

\subsection{Supply Chain Linkages}

Numerous literatures have discussed the supply chain linkages concept (Hong \& Jeong, 2006; Lee, Kwon, \& Severance, 2007; Rungtusanatham, Salvador, Forza, \& Choi, 2003; Ibrahim \& Ogunyemi, 2012; Thakkar, Deshmukh, \& Kanda, 2008; Zelbst, Sower, \& Reyes, 2009). In general, supply chain linkages is the firm's blueprint to make decisions related to supply chain activities e.g. investment, purchasing and production (Rungtusanatham et al., 2003). In practice, supply chain linkages is also cited as an application of information technology 
involving with the efforts to plan and implement integrated processes and operations (Hong \& Jeong, 2006). In a study by Ibrahim and Ogunyemi, (2012) supply chain linkages was viewed as reinforcement to deliver and to obtain meaningful information with a motive to improve a firm's competitiveness. Examining a proportion of supply chain practices in small and medium industry, the percentage of application of supply chain linkages in their business is low due to knowledge deficiency (Hong \& Jeong, 2006). Various factors of supply chain linkages have been established in earlier studies. However, factors of supply chain linkages that are highlighted in this study are information sharing, development programme and outsourcing.

\section{(a) Information Sharing}

Information sharing is an action of viewing channel member's private data and an ability to observe the products progress at each stage in supply chain process (Chamhuri \& Batt, 2005). Some firms are not hesitant to provide accurate information to their supply chain members (Jain, Seshadri, \& Sohoni, 2011). Other advantages of information sharing are, firms can better understand what customers need and able to respond promptly on market changes (Kocoglu, Imamoglu, Ince, \& Keskin, 2011). In Malaysia, there is a small proportion of information sharing activity occurring among supply chain members (Kaliappan et al., 2009). From large firms perspective, smaller firms should contribute more in information sharing (Chuah, Wong, Ramayah, \& Jantan, 2010). In addition, information sharing among supply chain members contributes to risk-sharing, especially during a stage of transferring the information (Kocoglu, et al. 2011). Information sharing has been previously proven to have a significant and positive relationship with business performance (Moberg, Cutler, Gross, \& Speh, 2002; Fawcett, Osterhaus, Magnan, Brau, \& McCarter, 2007; Sanders, Autry, \& Gligor, 2011; Sundram, Ibrahim, \& Govindaraju, 2011). Sanders et al. (2011) expect that the ultimate cause of achieving good firms' performance is by sharing truthful information at a strategic and operational level. In a comparison study, the firms that practiced information sharing achieves better performance than the firms that do not (Fawcett, et al., 2007). Therefore, it is hypothesized that:

H1: There is a significant and positive relationship between information sharing and business performance.

\section{(b) Development Programme}

Development programme refers to a medium to start or to improve the relationship if it has not yet existed (Arroyo-Lopez, Holmen \& Boer, 2012). Past studies have also highlighted the challenges of the development programme. Even though involvement in development programme is identified as to assist firms, the majority of them are hesitant to provide capital supports to low-performance suppliers (Wagner, 2006). Foreign firms tend to be more selfcentric, incline to provide training and unwilling to visit their supply chain members (Chuah et al., 2010). Previous studies also reported that only small proportion of firms participate in development programme (Arroyo-Lopez et al., 2012). Nonetheless, development programme has been used to analyse firms' performance. Earlier studies have confirmed that development programme has significantly increased the firms' performance (Millington, Eberhardt, Wilkinson, 2006). The firms are able to achieve better performance when they participate in 
more development activities (Sanchez-Rodriguez, Hemsworth, \& Martinez-Lorente, 2005). For instance, doing regular visit and forming a supplier development team could improve firms' performance (Krause, Handfield, \& Tyler, 2007). Finding from Cooke and Wills (1999) is in line with social capital theory where activity development is associated with the improvement of firms' performance. In addition, Krause et al. (2007) discover that development activity presents quality, flexibility and delivery performance of the organizations. Therefore, it is hypothesized that:

H2: There is a significant and positive relationship between development programme and business performance.

\section{(c) Outsourcing}

Outsourcing refers to a contract of giving permission to transfer particular in-house activities to be executed by external providers (Ghodeswar \& Vaidyanathan, 2008). The main objective to outsource activities is for financial benefits (Earl,1996; Ghodeswar \& Vaidyanathan, 2008; Hamzah, Aman, Maelah, Auzair \& Amiruddin, 2010; Jiang, Frazier, \& Prater, 2006; Lau \& Zhang, 2006; McIvor, 2000) which enable the firms to achieve a lower cost advantage (McIvor, 2000) such as to cut short-term cost (Hamzah et al., 2010) as well as to reduce capital investment in manufacturing, transportation, warehousing, and information technology (Jiang, Frazier, \& Prater, 2006; Lau \& Zhang, 2006). Although outsourcing is able to cut costs, firms are threaten by the risks of supervising their supply chain members and failure of their outsourcing activity (McIvor, 2008). Past studies found that there is a significant relationship between outsourcing and firms' performance (Abdul-Aziz and Ali, 2004; Bolat \& Yilmaz, 2009; Elmuti, 1999; Larson \& Kulchitsky, 1999). Outsourcing has been proven to have a positive impact on the logistic performance. Few studies have examined the outsourcing by observing the causes and motives of outsourcing (Elmuti, 1999). In comparison between before and after outsourcing adoption, the firms show positive improvement after the adoption of outsourcing (Bolat \& Yilmaz, 2009). The success of outsourcing is because providers are incontact with the firms through meetings and advice sessions (Abdul-Aziz and Ali, 2004). The firms have the potential to develop their skill and service quality, reduce employees and cost as well as save time (Elmuti, 1999). In consistent with the resource-based view, the higher level of outsourcing has given direct impact on the firms competitiveness (Sanders et al., 2011). Thus, it is hypothesized that:

H3: There is a significant and positive relationship between outsourcing and business performance.

\section{METHODOLOGY}

\subsection{Sampling}

The sampling frame used in this study was the list of enterprises owned by Bumiputera ${ }^{2}$ entrepreneurs in Sarawak. The listing is considered as accurate because it is published by the

2 Malay and other indigenous people 
state government of Sarawak. Among the eight areas in Sarawak, Kuching was chosen for the highest number of enterprises operated in this city (Sarawak Chief Minister's Office, 2010). With the population of 2548 enterprises, the sample size of 214 with margin of error of $6.54 \%$ was calculated using Solvin's formula. By way of a convenient sampling, the owners or top management employees of the micro and small enterprises were chosen as the unit of analysis with the assumption that they were the most suitable person to respond (Chen \& Paulraj, 2004).

\subsection{Research Instrument}

The questionnaire was designed using items that have been tested previously by Fan (2000); Fynes, Voss, and Burca (2005); Kroes and Ghosh (2010); Sanchez-Rodriguez et al. (2005); Ibrahim and Ogunyemi (2012); Jusoh (1995). The questionnaire comprises of six sections. Four of which were measured using a five-point Likert scale. The scale used for information sharing, development programme and outsourcing sections describe the level of respondents' agreement or disagreement while the business performance section was measured using objective measurement. The final section measured the respondents' background information.

\subsection{Data Collection Method}

A self-administered survey was carried out which allows the respondents to complete the questionnaire at their own convenience. The questionnaire was distributed within two months by contacting the potential respondents directly. Direct approach is chosen for its accuracy and completeness of the questionnaire (Brinkman, 2009). Out of 350 sets of questionnaire distributed, 214 sets are usable for analysis.

\section{DATA ANALYSIS AND FINDINGS}

\subsection{Respondents' and Business Profile}

The majority of the respondents were owners (78.5\%) and female (50.9\%). Most of them were between 41 to 45 years old $(18.7 \%)$ and married $(72.9 \%)$. The analyses showed that the majority of the respondents have up to secondary school level qualifications (43.9\%) and new in business, that is, from 1 to 5 years business experience (4.2\%). From the total of 214 enterprises, $60.3 \%$ were micro-size business and fall under the service sector $(20.6 \%)$. The length of operation was between 1 to 5 years $(41.1 \%)$ and the businesses were established by the owners $(73.8 \%)$ themselves.

\subsection{Factor Analysis}

Factor analysis was performed on the 12 items of the independent variables in order to reduce the total number of items to a more manageable number (Lee et al., 2007). The Keiser-MeyerOlkin (KMO) and Barlett's test of Sphericity are performed to confirm if factor analysis could be done or not (Tabachnick \& Fidell, 2001). The KMO value is 0.732 and the Barlett's test is statistically significant (Chi-Square $=649.986, \mathrm{p}<0.001$ ) which is adequate for factor reduction procedure. After five iterations, three components were extracted with Eigenvalues 
more than 1 and contributing $63.94 \%$ of the total variance. The three factors were named as information sharing, development programme and outsourcing.

\subsection{Reliability Analysis}

Reliability analysis was then performed to test the accuracy, precision and internal consistency of the items (Cooper \& Schindler, 2008). Table 2 showed the results of the reliability test. The Cronbach's alpha of the four factors in the table is considered as acceptable since all are above 0.7 (Sekaran, 2000).

Table 2: Reliability Statistics of Extracted Factors

\begin{tabular}{lcc}
\hline \multicolumn{1}{c}{ Dimensions } & $\begin{array}{c}\text { No of items } \\
\text { tested }\end{array}$ & Cronbach's Alpha \\
\hline Information Sharing & 4 & 0.765 \\
Development Programme & 3 & 0.744 \\
Outsourcing & 3 & 0.748 \\
Business Performance & 6 & 0.796 \\
\hline
\end{tabular}

\subsection{Correlation}

Based on the Pearson correlation analysis between independent variables; information sharing, development programme and outsourcing and dependent variable; business performance, showed that all the independent variables were significantly correlated with the dependent variable at 0.000 significance level. The strength of correlation coefficient referred to the rule of thumb provided by Hair, et al. (2009). Coefficient range from 0.81 to 1.00 is very strong, 0.61 to 0.80 is strong, 0.41 to 0.60 is moderate, 0.21 to 0.40 is weak with low correlation, and 0.00 to 0.20 is very weak to no relationship at all. The correlation coefficient indicates that there was a weak positive correlation between information sharing and business performance $(r=0.348, p=0.000)$, a moderate positive correlation between development programme and business performance $(r=0.418, p=0.000)$ and a weak positive correlation between outsourcing and business performance $(r=0.231, p=0.000)$.

\subsection{Multiple Regression Analysis}

Multiple regression analysis was performed and the results were summarized in Table 3. The results showed that the $\mathrm{R}$ square of the model was 0.224 which means that $22.4 \%$ of the variance in business performance (dependent variable) can be explained by the three independent variables namely information sharing, development programme and outsourcing. The results of the ANOVA test showed that the model is statistically significant (sig. $=0.000$, $p<0.05$ ) with F-value 20.175. The result indicated that only two out of the three indicators of the supply chain linkages were significantly related to business performance. The standardised beta coefficient indicates the relative importance of each of the indicators. Development programme $(\beta=0.328, p=0.000)$, generated the largest positive and significant influence on performance and this is followed by information sharing $(\beta=0.223, p=0.001)$. Although 
outsourcing $(\beta=0.041, \mathrm{p}=0.547)$ showed a positive influence towards performance but it was not statistically significant.

Table 3: Multiple Regressions Analysis

\begin{tabular}{lccc}
\hline & $\begin{array}{c}\text { Standardised Coefficient } \\
\text { (Beta) }\end{array}$ & t-value & Sig. \\
\hline Information Sharing & 0.223 & 3.324 & 0.001 \\
Development & 0.328 & 4.897 & 0.000 \\
Programme & 0.041 & 0.604 & 0.547 \\
Outsourcing & & \\
& & \\
Dependent Variable: Business Performance & & \\
R Square $=0.224$ & & \\
Adjusted R Square $=0.213$ & & \\
F-Value $=20.175$ & & \\
Sig. $=0.000$ & & \\
\hline
\end{tabular}

\subsection{Hypotheses Testing}

Based on the results above, it can be concluded that two out of three hypotheses proposed earlier were supported (Table 4).

Table 4: Hypotheses Testing

\begin{tabular}{llc}
\hline \multicolumn{1}{c}{ Hypotheses } & Findings \\
\hline $\mathbf{H}_{1}:$ & $\begin{array}{l}\text { There is a significant and positive relationship between } \\
\text { information sharing and business performance. }\end{array}$ & Supported \\
$\mathbf{H}_{2}:$ & $\begin{array}{l}\text { There is a significant and positive relationship between } \\
\text { development programme and business performance. }\end{array}$ & Supported \\
$\mathbf{H}_{3}:$ & $\begin{array}{l}\text { There is a significant and positive relationship between } \\
\text { outsourcing and business performance. }\end{array}$ & $\begin{array}{c}\text { Not } \\
\text { supported }\end{array}$ \\
\hline
\end{tabular}

\section{DISCUSSIONS AND CONCLUSION}

The supply chain is considered as an important function in business and non-business entity (Hong \& Jeong, 2006). Yet, small and medium industry fails to gain the advantages of supply chain (Vaaland \& Heide, 2007). The enterprises have to confront with the challenges such as cost and risk at the initial stage of implementation. Three predictors of supply chain linkages namely information sharing, development programme and outsourcing were examined on their effect on performance. The multiple regression analysis shows that the performance of micro and small enterprises is found to be significantly influenced by information sharing. The result is in line with the resource-based theory where firms with resources and capabilities and 
permit information sharing activity, will have improved business performances. This result is consistent with Fawcett et al. (2007) who compared firms that practice and do not practice information sharing. Firms with information sharing are able to perform better. In line with past studies, exchanging information is important in improving firm performance (Moberg et al., 2002). In addition, the multiple regression analysis also showed that the performance of micro and small enterprises is found to be significantly influenced by development programme. The finding supports earlier studies in which, involvement in development activities have a significant relationship with firm performance (Krause et al., 2007). This is consistent with Millington et al. (2006) and Sanchez-Rodriguez (2009) confirming that development programme has significantly improved the firm's performance. This finding also lends support to social capital theory where development activities are related to the improvement of business performance. Cooke and Wills (1999) also apply capital social theory in their empirical study and found respondents recognize the activities conducted result into a positive impact towards business performance.

In conclusion, this study found two factors that significantly influence the performance of micro and small enterprises in Kuching city, namely information sharing and development programme. Development programme was found to be the most influential factor that affects firm performance. This study has a few limitations that might affect its interpretations of the study findings. First, the sample of this study as confined to micro and small enterprises located in one city only. Future studies may expand the scope of the areas to include more cities, so that results can be generalized to a larger population. In this study, only three predictors were investigated. The findings also show that these three predictors only predict slightly more than 20 percent of the variance in performance. Future studies should also investigate the effect of uncertainty factors in addition to the ones that were investigated in this present study.

\section{REFERENCES}

Abdul-Aziz, A. R., \& Ali, N. (2004). Outsourcing and quality performance: Malaysia's public works department. Structural Survey, 22(1), 53-60. doi:10.1108/02630800410530927

Abdul-Halim, H., Ahmad, N. H., \& Ramayah, T. (2012). Unveiling the motivation to outsource among SMEs. Business Strategy Series, 13(4), 181-186. doi:10.1108/17515631211246258

Arroyo-Lopez, P., Holmen, E., \& Boer, L. D. (2012). How do supplier development programs affect suppliers?: Insights for suppliers, buyers and governments from an empirical study in Mexico. Business Process Management Journal, 18(4), 680-707. doi: $10.1108 / 14637151211253792$

Bolat, T., \& Yilmaz, O. (2009). The relationship between outsourcing and organizational performance: Is it myth or reality for the hotel sector? International Journal of Contemporary Hospitality Management, 21(1), 7-23. doi:10.1108/09596110910930151 
Brinkman, W. (2009). Design of a Questionnaire Instrument. Handbook of Mobile Technology Research Methods, 31-57.

Chamhuri, N., \& Batt, P. J. (2005). Factors influencing consumers' choice of retail stores for fresh meat in Malaysia. Perth. Retrieved March 8, 2011 from http://eoq.hu/iama/ conf/1017_paper.pdf

Chen, I. J., \& Paulraj, A. (2004). Towards a theory of supply chain management: the constructs and measurements. Jounal of Operations Management, 22(2), 119-150. doi:10.1016/j. jom.2003.12.007

Chuah, P., Wong, W. P., Ramayah, T., \& Jantan, M. (2010). Organizational context, supplier management practices and supplier performance: A case study of a multinational company in Malaysia. Journal of Enterprise Information Management, 23(6), 724-758. doi:10.1108/17410391011088619

Cooke, P., \& Wills, D. (1999). Small firms, social capital and the enhancement of business performance through innovation programmes. Small Business Economics, 13(3), 219234.

Cooper, D. R., \& Schindler, P. S. (2008). Business Research Methods (International). New York: McGraw-Hill.

Earl, M. J. (1996). The risks of outsourcing IT. Sloan Management Review, 37(3), 26-32.

Elmuti, D. (1999). The perceived impact of outsourcing on organizational performance. MidAmerican Journal of Business, 18(2), 33-42.

Fabbe-costes, N., \& Jahre, M. (2007). Supply chain integration improves performance: the emperor's new suit? International Journal of Physical Distribution \& Logistics Management, 37(10), 835-855. doi:10.1108/09600030710848941

Fan, Y. (2000). Strategic outsourcing: evidence from British companies. Marketing Intelligence \& Planning, 18(4), 213-219.

Fawcett, S. E., Osterhaus, P., Magnan, G. M., Brau, J. C., \& McCarter, M. W. (2007). Information sharing and supply chain performance: the role of connectivity and willingness. Supply Chain Management: An International Journal, 12(5), 358-368. doi:10.1108/13598540710776935

Fynes, B., Voss, C., \& Búrca, S. D. (2005). The impact of supply chain relationship dynamics on manufacturing performance. International Journal of Operations \& Production Management, 25(1), 6-19. doi:10.1108/01443570510572213 
Ghodeswar, B., \& Vaidyanathan, J. (2008). Business process outsourcing: an approach to gain access to world-class capabilities. Business Process Management Journal, 14(1), 23-38. doi: $10.1108 / 14637150810849382$

Gunasekaran, A., Patel, C., \& Mcgaughey, R. E. (2004). A framework for supply chain performance measurement. Int. J. Production Economics, 87(3), 333-347. doi:10.1016/j. ijpe.2003.08.003

Hair, J. F., Bush, R. P., \& Ortinau, D. J. (2009). Marketing research: In a digital information environment (Fouth Edit., pp. 312-316). New York: McGraw-Hill.

Hamzah, N., Aman, A., Maelah, R., Auzair, S., \& Amiruddin, R. (2010). Outsourcing decision processes : A case study of a Malaysian firm. African Journal of Business Management, $4(15), 3307-3314$.

Hashim, J. (2007). Information communication technology (ICT) adoption among SME owners in Malaysia. International Journal of Business and Information, 2(2), 221-240.

Hashim, M. K., \& Abdullah, M. S. (2000). SMEs in the Malaysian manufacturing sector: A proposal for redefining SMEs and a study on the firm characteristic-performance relationships. Arau, Perlis: MARA University of Technology.

Hong, P., \& Jeong, J. (2006). Supply chain management practices of SMEs: from a business growth perspective. Journal of Enterprise Information Management, 19(3), 292-302. doi:10.1108/17410390610658478

Ibrahim, S. E., \& Ogunyemi, O. (2012). The effect of linkages and information sharing on supply chain and export performance: An empirical study of Egyptian textile manufacturers. Journal of Manufacturing Technology Management, 23(4), 441-463. doi:10.1108/17410381211230394

Jain, A., Seshadri, S., \& Sohoni, M. (2011). Differential pricing for information sharing under competition. Production and Operations Management Society, 20(2), 235-252.

Jiang, B., Frazier, G. V., \& Prater, E. L. (2006). Outsourcing effects on firms' operational performance: An empirical study. International Journal of Operations \& Production Management, 26(12), 1280-1300. doi:10.1108/01443570610710551

Jusoh, W. J. W. (1995). Determinants of success in new product development: An exploratory investigation of manufacturing companies in Malaysia. Glasgow: University of Strathclyde.

Kaliappan, S. R., Alavi, R., Abdullah, K., \& Zakaullah, M. A. (2009). Spillover effects of foreign hypermarkets on domestic suppliers in Malaysia. International Journal of Retail \& Distribution Management, 37(3), 226-249. doi:10.1108/09590550910941508 
Kee, D. M. H., Effendi, A. A., Abdul Talib, L. S., \& Abdul Rani, N. A. (2010). A premilinary study of top SMEs in Malaysia: Key success sactor vs government support program. Journal of Asia Entrepreneurship and Sustainability, 4(1), 111-119.

Kementerian Kewangan Malaysia. (2003). Prestasi dan prospek ekonomi. Malaysia: Kementerian Kewangan Malaysia.

Kocoglu, I., Imamoglu, S. Z., Ince, H., \& Keskin, H. (2011). The effect of supply chain integration on information sharing:Enhancing the supply chain performance. Procedia Social and Behavioral Sciences, 24, 1630-1649. doi:10.1016/j.sbspro.2011.09.016

Krause, D. R., Handfield, R. B., \& Tyler, B. B. (2007). The relationships between supplier development, commitment, social capital accumulation and performance improvement. Journal of Operations Management, 25(2), 528-545. doi:10.1016/j.jom.2006.05.007

Kroes, J. R., \& Ghosh, S. (2010). Outsourcing congruence with competitive priorities: Impact on supply chain and firm performance. Journal of Operations Management, 28(2), 124143. doi:10.1016/j.jom.2009.09.004

Larson, P. D., \& Kulchitsky, J. D. (1999). Logistics improvement programs: The dynamics between people and performance. International Journal of Physical Distribution \& Logistics Management, 29(2), 88-102.

Lau, K. H. \& Zhang, J. (2006). Drivers and obstacles of outsourcing practices in China. International Journal of Physical Distribution \& Logistics Management, 36(10), 776792.

Lee, C. W., Kwon, I-W. G., \& Severance, D. (2007). Relationship between supply chain performance and degree of linkage among supplier, internal integration, and customer. Supply Chain Management: An International Journal, 6(12), 444-452. doi:10.1108/13598540710826371

Mahalingam, E. (2012, October 6). Recharging the SME industry. The Star. Retrieved from http://www.thestar.com.my/business/business-news/2012/10/06/recharging-the-smeindustry/?style $=$ biz

McIvor,R.(2000).Apractical framework forunderstanding theoutsourcing process. Supply Chain Management: An International Journal, 5(1), 22-36. doi:10.1108/13598540010312945

McIvor, R. (2008). What is the right outsourcing strategy for your process? European Management Journal, 26(1), 24-34. doi:10.1016/j.emj.2007.08.008

Millington, A., Eberhardt, M., \& Wilkinson, B. (2006). Supplier performance and selection in China. International Journal of Operations \& Production Management, 26(2), 185-201. doi:10.1108/01443570610641666 
Moberg, C. R., Cutler, B. D., Gross, A., \& Speh, T. W. (2002). Identifying antecedents of information exchange within supply chains. International Journal of Physical Distribution \& Logistics Management, 32(9), 755-770. doi:10.1108/09600030210452431

Ong, J. W., Hishamuddin, I., \& Yeap, F. P. (2010). Malaysian small and medium enterprises: The fundamental problems and recommendations for improvement. Journal of Asia Entrepreneurship and Sustainability, 4(1), 39-48.

Rungtusanatham, M., Salvador, F., Forza, C., \& Choi, T. Y. (2003). Supply-chain linkages and operational performance: A resource-based-view perspective. International Journal of Operations \& Production Management, 23(9), 1084-1099. doi:10.1108/01443570310491783

Saleh, A. S., \& Ndubisi, N. O. (2006). An evaluation of sme development in malaysia. International Review of Business Research Papers, 2(1), 1-14.

Sanchez-Rodriguez, C. (2009). Effect of strategic purchasing on supplier development and performance: a structural model. Journal of Business \& Industrial Marketing, 24(3), 161172. doi:10.1108/08858620910939714

Sanchez-Rodriguez, C., Hemsworth, D., \& Martinez-Lorente, Á. R. (2005). The effect of supplier development initiatives on purchasing performance: a structural model. Supply Chain Management: An International Journal, 10(4), 289-301. doi: $10.1108 / 13598540510612767$

Sanders, N. R., Autry, C. W., \& Gligor, D. M. (2011). The impact of buyer firm information connectivity enablers on supplier firm performance A relational view. The International Journal of Logistics Management, 22(2), 179-201. doi:10.1108/09574091111156541

Sarawak Chief Minister's Office. (2010). Directory of Sarawak Bumiputera Entrepreneurs. Kuching.

Schmitz, J., \& Platts, K. W. (2003). Roles of supplier performance measurement : indication from a study in the automotive industry. Management Decision, 41(8), 711-721. doi: $10.1108 / 00251740310496224$

Sekaran, U. (2000). Research methods for business: A skill building approach. New York: John Wiley \& Sons.

Shepherd, C., \& Günter, H. (2006). Measuring supply chain performance: current research and future directions. International Journal of Productivity and Performance Management, 55(3/4), 242-258. doi:10.1108/17410400610653219 
Sundram, V. P. K., Ibrahim, A. R. \& Govindaraju, V. G. R. C. (2011). Supply chain management practices in the electronics industry in Malaysia: Consequences for supply chain performance. Benchmarking: An International Journal, 18(6), 834-855. doi:10.1108/14635771111180725

Tabachnick, B. G., \& Fidell., L. S. (2001). Using multivariate statistics (Fourth Edi.). Boston, MA: Allyn \& Bacon.

Thakkar, J., Deshmukh, S. G., \& Kanda, A. (2008). Supply chain management in SMEs: development of constructs and propositions. Asia Pacific Journal of Marketing and Logistics, 20(1), 97-131. doi:10.1108/13555850810844896

The Borneo Post. (2012). Malaysia needs more competitive, resilient SMEs. Retrieved June 6, 2013, from http://www.theborneopost.com/2012/11/12/malaysia-needs-morecompetitive-resilient-smes-says-mustapa/

Vaaland, T. I., \& Heide, M. (2007). Can the SME survive the supply chain challenges? Supply Chain Management: An International Journal, 12(1), 20-31. doi:10.1108/13598540710724374

Wagner, S. M. (2006). Supplier development practices: an exploratory study. European Journal of Marketing, 40(5/6), 554-571. doi:10.1108/03090560610657831

Zelbst, P. J., Jr, K. W. G., Sower, V. E., \& Reyes, P. (2009). Impact of supply chain linkages on supply chain performance. Industrial Management \& Data Systems, 109(5), 665-682. doi:10.1108/02635570910957641 